\title{
Efficacy of different limestone particle size and 25-hydroxycholecalciferol in broiler diets*
}

\author{
J. Koreleski ${ }^{1}$ and S. Świątkiewicz \\ National Research Institute of Animal Production, \\ Department of Animal Nutrition and Feed Sciences \\ 32-083 Balice, Poland
}

(Received 13 June 2005; accepted 17 October 2005)

\begin{abstract}
In a 6-week experiment on 560 Cobb broilers, the response of chickens to supplementation of diets with particulate grit and 25-hydroxycholecalciferol $\left(25-\mathrm{OH}-\mathrm{D}_{3}\right)$ was evaluated. Maize- and soyabean meal-based diets contained pulverized limestone or a mixture of $70 \%$ pulverized and $30 \%$ particulate (1.2-4 $\mathrm{mm}$ in diameter) limestone as a source of calcium. Both diets were supplemented with vitamin $\mathrm{D}_{3}$ (cholecalciferol) or $25-\mathrm{OH}-\mathrm{D}_{3}$ was substituted in amounts equivalent to $20,40,50$, 60,80 , or $100 \%$ of cholecalciferol.

Incorporation of particulate forms of limestone into the diet positively affected performance and the ash and Ca contents in the tibia. Replacement of cholecalciferol by $25-\mathrm{OH}-\mathrm{D}_{3}$ at a level of 50 and $60 \%$ had a beneficial effect on body weight gain and feed conversion, $100 \%$ substitution, on the $\mathrm{Ca}$ content of the tibia, whereas 50, 60, 80 and $100 \%$ substitution, on $\mathrm{Ca}$ and $\mathrm{P}$ balance.
\end{abstract}

KEY WORDS: broilers, cholecalciferol, 25-OH- $\mathrm{D}_{3}$, limestone form, performance, tibia bones, calcium, phosphorus

\section{INTRODUCTION}

Adequate dietary levels of calcium, phosphorus and vitamin $\mathrm{D}$ are required for chicken growth and normal bone development. Utilization of dietary calcium carbonate by chickens may depend more on particle size than origin. Guinotte et al. (1991) found that in comparison with ground calcium carbonate $(<0.15 \mathrm{~mm})$, coarse particles $(>1.18 \mathrm{~mm})$ incorporated into the diet diminished weight gain

\footnotetext{
* Supported by the State Committee for Scientific Research, Grant No. 6 PO6Z 01421

${ }^{1}$ Corresponding author: e-mail: jerzy.koreleski@izoo.krakow.pl
} 
and feed conversion, tibia characteristics and ash content, and decreased calcium retention. In contrast, in a study by Zohravi (2002) the incorporation of coarse particle limestone $(1.18-4.75 \mathrm{~mm})$ into the diet significantly improved the feed conversion ratio, tibia ossification and $\mathrm{Ca}$ and $\mathrm{P}$ retention.

Cholecalciferol is supplemented to practical diets for broiler chickens in large amounts and is transformed in tissues to active metabolites (Collins and Norman, 1991). The occurrence of signs of rickets and dyschondroplasia in chickens fed practical diets rich in vitamin $\mathrm{D}_{3}$ may suggest that transformation of cholecalciferol in the liver and kidney to $25-\mathrm{OH}-\mathrm{D}_{3}$ and $1,25-(\mathrm{OH})_{2}-\mathrm{D}_{3}$ is not sufficient. Both active metabolites added to the diet were found to be effective sources of vitamin $\mathrm{D}_{3}$ (Edwards, 1990; Rennie and Whitehead, 1996). Yarger et al. (1995) reported better performance of birds fed $25-\mathrm{OH}-\mathrm{D}_{3}$ in comparison with those fed vitamin $\mathrm{D}_{3}$ at a dietary level of $2760 \mathrm{IU} \cdot \mathrm{kg}^{-1}$.

The present study was undertaken to evaluate the responses of broilers to diets containing pulverized limestone or mixed particulate grit and a pulverized form of limestone, and cholecalciferol alone or gradually substituted by $25-\mathrm{OH}-\mathrm{D}_{3}$.

\section{MATERIAL AND METHODS}

A 6-week experiment was carried out on 560 Cobb broiler chickens. Sexed day-old chickens were allotted to 14 groups in 5 replicates, each containing 4 males and 4 females, and kept in cages with wire mesh floors. The diets provided in the first (starter, 1-21 days) and second (grower-finisher, 22-42 days) feeding periods contained pulverized limestone or a mixture of $70 \%$ pulverized and $30 \%$ particulate (1.2-4 mm mesh) limestone as the calcium source. The starter and grower-finisher diets (Table 1) were supplemented with 2000 and $1500 \mathrm{IU}$ of cholecalciferol $\cdot \mathrm{kg}^{-1}$, respectively (as Lutavit 500, BASF). The diets for groups I and VIII were supplemented only with vitamin $\mathrm{D}_{3}$; in the diets for the other groups, the $25-\mathrm{OH}$-derivative replaced $20,40,50,60,80$ or $100 \%$ of the cholecalciferol (Table 2). The source of $25-\mathrm{OH}-\mathrm{D}_{3}$ (Hy.D Beadlet, DSM) contained $12.5 \mathrm{mg}$ $25-\mathrm{OH}-\mathrm{D}_{3}$ per $\mathrm{g}$, which was equivalent to $500000 \mathrm{IU}$ of vitamin $\mathrm{D}_{3}$.

Body weight and feed intake were measured, mortality was registered and body weight gain (BWG) and feed conversion ratio (FCR) were calculated for the first and second periods of feeding and for the whole experiment. On the basis of body weight gain, feed conversion and mortality, the performance efficiency index (EPE-index) was calculated. Between days 15 to 19 of life, feed intake was measured and total collection of excreta from each pen was carried out in groups I-VII fed pulverized limestone. Excreta were stored at $-20^{\circ} \mathrm{C}$. After thawing, the excreta were dried in an oven at $50^{\circ} \mathrm{C}$, left on air for two days, 
TABLE 1

Composition of diets, $\mathrm{g} \cdot \mathrm{kg}^{-1}$

\begin{tabular}{|c|c|c|}
\hline Item & Starter & Grower/Finisher \\
\hline \multicolumn{3}{|l|}{ Component } \\
\hline ground maize & 533.6 & 582.5 \\
\hline soyabean meal & 385.0 & 325.0 \\
\hline rapeseed oil & 40.0 & 50.0 \\
\hline limestone & 9.0 & 9.0 \\
\hline dicalcium phosphate & 20.0 & 20.5 \\
\hline $\mathrm{NaCl}$ & 3.0 & 3.0 \\
\hline DL-methionine & 2.3 & 2.2 \\
\hline L-lysine $\mathrm{HCl}$ & 2.1 & 2.8 \\
\hline vitamin-mineral premix ${ }^{1}$ & 5.0 & 5.0 \\
\hline \multicolumn{3}{|l|}{ Analysed } \\
\hline crude protein & 215 & 195 \\
\hline Lys & 13.3 & 12.5 \\
\hline Met & 5.6 & 5.3 \\
\hline $\mathrm{Ca}$ & 9.0 & 9.0 \\
\hline total $\mathrm{P}$ & 7.65 & 7.65 \\
\hline $\mathrm{MJ} \cdot \mathrm{kg}^{-12}$ & 12.25 & 12.7 \\
\hline \multicolumn{3}{|c|}{ 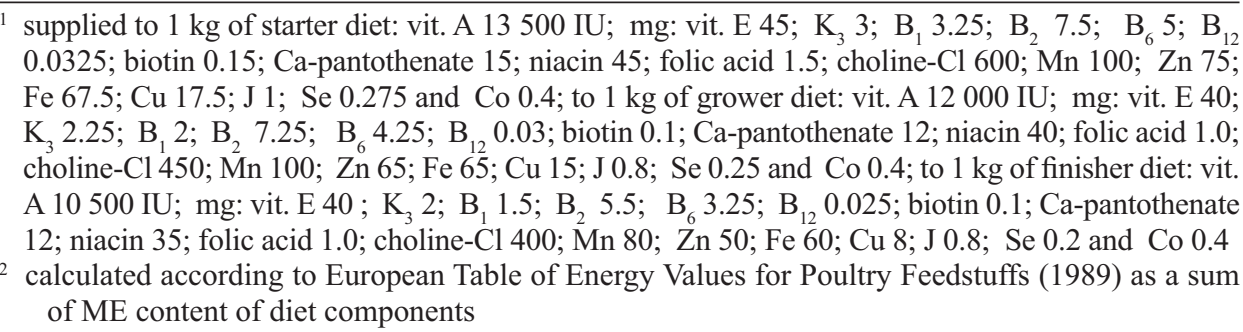 } \\
\hline
\end{tabular}

weighed and homogenized. In the samples of diets and excreta, the $\mathrm{Ca}$ content was determined by flame atomic absorption spectrophotometry using a Philips PU 9100 apparatus and the P content was determined colorimetrically by the molybdo-vanadate method (AOAC, 1990). Lysine and methionine were analysed in the basal diet in acid hydrolysates in a colour reaction with the ninhydrin reagent, using a Beckman-System Gold 126 AA automatic analyser. Methionine was estimated after preoxidation to methionine sulphone.

On day 43 of age, 8 chickens ( 4 males and 4 females) from each group were slaughtered by decapitation, plucked, eviscerated and the carcasses were cooled. On the next day the carcass and gizzard were weighed, breast muscles $(M$. pectoralis maior and minor) from each carcass were excised and weighed. Eight tibia bones per replicate were collected, dried at $100^{\circ} \mathrm{C}$ for $24 \mathrm{~h}$, weighed, and dryashed at $600^{\circ} \mathrm{C}$ for determination of crude ash and Ca. 
TABLE 2

Scheme of the experiment

\begin{tabular}{|c|c|c|c|c|c|c|}
\hline \multirow{2}{*}{$\begin{array}{l}\text { Group } \\
\text { No. }\end{array}$} & \multirow{2}{*}{$\begin{array}{c}\text { Pulverized } \\
\text { limestone } \\
\%\end{array}$} & \multirow{2}{*}{$\begin{array}{c}\text { Particulate } \\
\text { limestone grit } \\
\%\end{array}$} & \multicolumn{2}{|c|}{ Starter } & \multicolumn{2}{|c|}{ Grower/Finisher } \\
\hline & & & $\begin{array}{c}\text { cholecalciferol } \\
\mathrm{IU} \cdot \mathrm{kg}^{-1}\end{array}$ & $\begin{array}{c}25-\mathrm{OH}-\mathrm{D}_{3} \\
\mathrm{IU} \cdot \mathrm{kg}^{-1}\end{array}$ & $\begin{array}{c}\text { cholecalciferol } \\
\mathrm{IU} \cdot \mathrm{kg}^{-1}\end{array}$ & $\begin{array}{c}25-\mathrm{OH}-\mathrm{D}_{3} \\
\mathrm{IU} \cdot \mathrm{kg}^{-1}\end{array}$ \\
\hline I & & & 2000 & - & 1500 & - \\
\hline II & & & 1600 & 400 & 1200 & 300 \\
\hline III & 100 & - & 1200 & 800 & 900 & 600 \\
\hline IV & & & 1000 & 1000 & 750 & 750 \\
\hline $\mathrm{V}$ & & & 800 & 1200 & 600 & 900 \\
\hline VI & & & 400 & 1600 & 300 & 1200 \\
\hline VII & & & - & 2000 & - & 1500 \\
\hline VIII & & & 2000 & & 1500 & - \\
\hline IX & & & 1600 & 400 & 1200 & 300 \\
\hline $\mathrm{X}$ & & & 1200 & 800 & 900 & 600 \\
\hline XI & 70 & 30 & 1000 & 1000 & 750 & 750 \\
\hline XII & & & 800 & 1200 & 600 & 900 \\
\hline XIII & & & 400 & 1600 & 300 & 1200 \\
\hline XIV & & & - & 2000 & - & 1500 \\
\hline
\end{tabular}

The data were subjected to statistical analysis using two-way analysis of variance, except $\mathrm{Ca}$ and $\mathrm{P}$ balance data, which were calculated using one-way analysis of variance. The significance of differences between means was determined by Duncan's multiple range test using the Statistica 5.0 PL software package.

\section{RESULTS}

In the first period of feeding (1-21 days of age) the performance of chickens was not affected by the kind of calcium source and vitamin $\mathrm{D}_{3}$ substitution (Table 3).

In the second period of feeding (Table 4), the replacement of pulverized limestone by particulate limestone had a positive effect on BWG $(\mathrm{P} \leq 0.001)$, feed intake $(\mathrm{P} \leq 0.05)$ and FCR $(\mathrm{P}<0.01)$. Chickens fed the diet supplemented with cholecalciferol had the lowest weight gain and feed intake. Substitution of $25-\mathrm{OH}-\mathrm{D}_{3}$ for cholecalciferol at a level of $50,60,80$ and $100 \%$ significantly improved BWG and FCR.

For the whole period of feeding (Table 5) the improvement of BWG and FCR was confirmed when the diet contained $30 \%$ limestone in particulate form $(\mathrm{P} \leq 0.001)$. Replacement of cholecalciferol at a level of 50 and $60 \%$ also positively 
TABLE 3

Performance in the first period of feeding (1-21 days of age)

\begin{tabular}{|c|c|c|c|c|c|c|c|c|c|}
\hline \multirow{3}{*}{$\begin{array}{l}\% \text { of } 25-\mathrm{OH}-\mathrm{D}_{3} \text { in } \\
\text { whole amount of } \\
\text { added vitamin } \mathrm{D}_{3}\end{array}$} & \multicolumn{3}{|c|}{ BWG, $g$} & \multicolumn{3}{|c|}{ Feed intake, $g$} & \multicolumn{3}{|c|}{ FCR, g feed $\cdot \mathrm{g} \mathrm{BWG}^{-1}$} \\
\hline & \multicolumn{9}{|c|}{$\%$ of grit in whole amount of used calcium carbonate } \\
\hline & 0 & 30 & mean & 0 & 30 & mean & 0 & 30 & mean \\
\hline 0 & 588 & 564 & 576 & 877 & 861 & 869 & 1.49 & 1.53 & 1.51 \\
\hline 20 & 577 & 547 & 562 & 854 & 828 & 841 & 1.49 & 1.52 & 1.50 \\
\hline 40 & 549 & 555 & 552 & 824 & 855 & 839 & 1.50 & 1.54 & 1.52 \\
\hline 50 & 591 & 556 & 573 & 864 & 820 & 842 & 1.46 & 1.48 & 1.47 \\
\hline 60 & 590 & 590 & 590 & 882 & 853 & 868 & 1.50 & 1.45 & 1.47 \\
\hline 80 & 573 & 573 & 573 & 858 & 855 & 856 & 1.50 & 1.49 & 1.50 \\
\hline 100 & 544 & 568 & 556 & 843 & 863 & 852 & 1.55 & 1.52 & 1.53 \\
\hline Mean & 573 & 565 & & 857 & 848 & & 1.50 & 1.50 & \\
\hline SEM & \multicolumn{2}{|c|}{4.01} & \multicolumn{4}{|c|}{3.95} & \multicolumn{3}{|c|}{0.0077} \\
\hline
\end{tabular}

all differences between means and interactions were not significant

TABLE 4

Performance in the second period of feeding (22-42 days of age)

\begin{tabular}{|c|c|c|c|c|c|c|c|c|c|}
\hline \multirow{3}{*}{$\begin{array}{l}\% \text { of } 25-\mathrm{OH}-\mathrm{D}_{3} \text { in } \\
\text { whole amount of } \\
\text { added vitamin } \mathrm{D}_{3}\end{array}$} & \multicolumn{3}{|c|}{ BWG, g } & \multicolumn{3}{|c|}{ Feed intake, $g$} & \multicolumn{3}{|c|}{$\mathrm{FCR}, \mathrm{g}$ feed $\cdot \mathrm{g} \mathrm{BWG}^{-1}$} \\
\hline & \multicolumn{9}{|c|}{$\%$ of grit in whole amount of used calcium carbonate } \\
\hline & 0 & 30 & mean & 0 & 30 & mean & 0 & 30 & mean \\
\hline 0 & 1603 & 1706 & $1655^{\mathrm{a}}$ & 3032 & 3037 & 3035 & 1.89 & 1.78 & $1.84^{\mathrm{c}}$ \\
\hline 20 & 1627 & 1734 & $1681^{\mathrm{ab}}$ & 3003 & 3191 & 3097 & 1.84 & 1.84 & $1.84^{\mathrm{c}}$ \\
\hline 40 & 1597 & 1763 & $1680^{\mathrm{ab}}$ & 2947 & 3147 & 3047 & 1.84 & 1.79 & $1.81^{b c}$ \\
\hline 50 & 1720 & 1793 & $1756^{\mathrm{bc}}$ & 3110 & 3052 & 3081 & 1.81 & 1.70 & $1.76^{\mathrm{a}}$ \\
\hline 60 & 1720 & 1782 & $1751^{\mathrm{bc}}$ & 3062 & 3139 & 3100 & 1.78 & 1.76 & $1.77^{\mathrm{ab}}$ \\
\hline 80 & 1689 & 1760 & $1725^{\mathrm{bc}}$ & 3057 & 3141 & 3099 & 1.81 & 1.79 & $1.80^{\mathrm{abc}}$ \\
\hline 100 & 1734 & 1788 & $1761^{c}$ & 3048 & 3140 & 3094 & 1.76 & 1.76 & $1.76^{\mathrm{a}}$ \\
\hline Mean & $1670^{x}$ & $1761^{y}$ & & $3037^{x}$ & $3121^{y}$ & & $1.82^{\mathrm{x}}$ & $1.77^{\mathrm{y}}$ & \\
\hline SEM & & 11.3 & & & 20.3 & & & 0.00830 & \\
\hline \multicolumn{10}{|l|}{ Effect of: } \\
\hline \multirow{3}{*}{$\begin{array}{l}\text { Ca source } \\
\text { vitamin } \mathrm{D}_{3} \\
\text { interaction }\end{array}$} & \multicolumn{3}{|c|}{$* * *$} & \multicolumn{3}{|c|}{$*$} & \multicolumn{3}{|c|}{$* *$} \\
\hline & \multirow{2}{*}{\multicolumn{3}{|c|}{ * }} & \multicolumn{3}{|c|}{ NS } & \multicolumn{3}{|c|}{$* *$} \\
\hline & NS & & & \multicolumn{3}{|c|}{ NS } & \multicolumn{3}{|c|}{ NS } \\
\hline
\end{tabular}

$x, y$ - values in the rows with different letters differ significantly $(\mathrm{P} \leq 0.05)$

a,b,c - values in the columns with different letters differ significantly $(\mathrm{P} \leq 0.05)$

NS - P $>0.05 ; *$ - $\mathrm{P} \leq 0.05 ; * *$ - $\mathrm{P} \leq 0.01 ; * * *$ - $\mathrm{P} \leq 0.001$

affected BWG and FCR. Improvement of the performance efficiency index was observed when $30 \%$ of the particulate calcium source was incorporated into the diet and $25-\mathrm{OH}-\mathrm{D}_{3}$ substituted for 50,60 and $100 \%$ of the cholecalciferol added to the diet. Experimental factors had no effect on the results of slaughter yield and on the percent of breast muscle and gizzard in the carcass (Table 6). 
The crude ash content in tibia bones (Table 7) differed significantly between chickens fed different forms of limestone, but substitution of $25-\mathrm{OH}-\mathrm{D}_{3}$ for vitamin $\mathrm{D}_{3}$ made no difference. The bone ash content in chickens fed pulverized limestone was lower than in groups fed mixed forms of limestone $(\mathrm{P} \leq 0.05)$. The calcium content in tibia bones (Table 7) was significantly affected by both

TABLE 5

Performance in the whole period of feeding (1-42 days of age)

\begin{tabular}{|c|c|c|c|c|c|c|c|c|c|c|c|c|}
\hline \multirow{3}{*}{$\begin{array}{l}\% \text { of } \\
25-\mathrm{OH}-\mathrm{D}_{3} \text { in } \\
\text { whole amount } \\
\text { of added } \\
\text { vitamin } \mathrm{D}_{3}\end{array}$} & \multicolumn{3}{|c|}{ BWG, $\mathrm{g}$} & \multicolumn{3}{|c|}{ Feed intake, $g$} & \multicolumn{3}{|c|}{$\mathrm{FCR}, \mathrm{g}$ feed $\cdot \mathrm{g}$ BWG ${ }^{-1}$} & \multicolumn{3}{|c|}{$\begin{array}{c}\text { Performance } \\
\text { efficiency index }\end{array}$} \\
\hline & \multicolumn{12}{|c|}{$\%$ of grit in whole amount of used calcium carbonate } \\
\hline & 0 & 30 & mean & 0 & 30 & mean & 0 & 30 & mean & 0 & 30 & mean \\
\hline & 2191 & 2270 & $2231^{\mathrm{a}}$ & 3910 & 3898 & 3904 & 1.78 & 1.72 & $1.75^{\mathrm{c}}$ & 296 & 319 & $308^{\mathrm{a}}$ \\
\hline 20 & 2204 & 2280 & $2242^{\mathrm{ab}}$ & 3857 & 4019 & 3938 & 1.75 & 1.76 & $1.76^{\mathrm{c}}$ & 304 & 313 & $309^{\mathrm{a}}$ \\
\hline 40 & 2146 & 2318 & $2232^{\mathrm{a}}$ & 3770 & 4002 & 3886 & 1.76 & 1.73 & $1.74^{\mathrm{bc}}$ & 295 & 324 & $309^{a}$ \\
\hline 50 & 2311 & 2349 & $2329^{\mathrm{bc}}$ & 3973 & 3871 & 3923 & 1.72 & 1.65 & $1.68^{\mathrm{a}}$ & 324 & 344 & $334^{\mathrm{b}}$ \\
\hline 60 & 2310 & 2373 & $2341^{\mathrm{c}}$ & 3944 & 3992 & 3968 & 1.71 & 1.68 & $1.69^{\mathrm{a}}$ & 326 & 340 & $333^{\mathrm{b}}$ \\
\hline 80 & 2262 & 2334 & $2298^{\mathrm{abc}}$ & 3914 & 3996 & 3955 & 1.73 & 1.71 & $1.72^{\mathrm{abc}}$ & 316 & 329 & $322^{\mathrm{ab}}$ \\
\hline 100 & 2277 & 2356 & $2317^{\mathrm{abc}}$ & 3890 & 4002 & 3947 & 1.71 & 1.70 & $1.70^{\mathrm{ab}}$ & 322 & 334 & $328^{b}$ \\
\hline Mean & $2243^{x}$ & $2326^{y}$ & & 3895 & 3969 & & $1.74^{x}$ & $1.71^{\mathrm{y}}$ & & $312^{\mathrm{x}}$ & $328^{y}$ & \\
\hline SEM & & 12.9 & & & 21.3 & & & 0.0062 & & & 2.4 & \\
\hline \multicolumn{13}{|l|}{ Effect of: } \\
\hline \multirow{3}{*}{$\begin{array}{l}\text { Ca source } \\
\text { vitamin } \mathrm{D}_{3} \\
\text { interaction }\end{array}$} & \multicolumn{3}{|c|}{$* * *$} & \multicolumn{3}{|c|}{ NS } & \multicolumn{3}{|c|}{$* * *$} & \multicolumn{3}{|c|}{$* * *$} \\
\hline & \multicolumn{3}{|c|}{$*$} & \multicolumn{3}{|c|}{ NS } & \multicolumn{3}{|c|}{$* * *$} & \multicolumn{3}{|c|}{$* * *$} \\
\hline & \multicolumn{3}{|c|}{ NS } & \multicolumn{3}{|c|}{ NS } & \multicolumn{3}{|c|}{ NS } & \multicolumn{3}{|c|}{ NS } \\
\hline
\end{tabular}

$x, y$ - values in the rows with different letters differ significantly $(\mathrm{P} \leq 0.05)$

a,b,c - values in the columns with different letters differ significantly $(\mathrm{P} \leq 0.05)$

NS - P $>0.05 ; *$ - $\mathrm{P} \leq 0.05 ; * * *-\mathrm{P} \leq 0.001$

treatment factors. In chickens fed pulverized limestone the $\mathrm{Ca}$ content in bones was lower than in groups fed mixed forms of limestone $(\mathrm{P} \leq 0.001)$. Complete replacement of cholecalciferol by $25-\mathrm{OH}-\mathrm{D}_{3}$ significantly increased the $\mathrm{Ca}$ content as compared with groups fed only vitamin $\mathrm{D}_{3}(\mathrm{P} \leq 0.05)$. An interaction was observed between limestone source and $\mathrm{D}_{3}$ substitution by $25-\mathrm{OH}-\mathrm{D}_{3}$.

A balance trial was conducted only in groups I-VII of chickens fed pulverized limestone (Table 8) because the excreta from groups fed the particulate limestone contained grit and were not susceptible to homogenization. The daily calcium retention in chickens was lowest when $100 \% \mathrm{D}_{3}$ was added to the diet as cholecalciferol and increased $(\mathrm{P} \leq 0.05)$ when $25-\mathrm{OH}-\mathrm{D}_{3}$ substituted for $60-100 \%$ of vitamin $\mathrm{D}_{3}$. Daily amounts of $\mathrm{Ca}$ excreted in excrements, and relative $\mathrm{Ca}$ retention (in \% of $\mathrm{Ca}$ ingested) did not differ statistically, however. Nevertheless a 
TABLE 6

Results of slaughter analysis

\begin{tabular}{|c|c|c|c|c|c|c|c|c|c|}
\hline \multirow{3}{*}{$\begin{array}{l}\% \text { of } 25-\mathrm{OH}-\mathrm{D}_{3} \text { in } \\
\text { whole amount } \\
\text { of added vitamin } \mathrm{D}_{3}\end{array}$} & \multicolumn{3}{|c|}{$\begin{array}{c}\text { Carcass yield, } \\
\%\end{array}$} & \multicolumn{3}{|c|}{$\begin{array}{c}\text { Breast meat yield, } \\
\% \text { carcass }\end{array}$} & \multicolumn{3}{|c|}{$\begin{array}{l}\text { Relative weight of } \\
\text { gizzard, \% carcass }\end{array}$} \\
\hline & \multicolumn{9}{|c|}{$\%$ of grit in whole amount of used calcium carbonate } \\
\hline & 0 & 30 & mean & 0 & 30 & mean & 0 & 30 & mean \\
\hline 0 & 73.1 & 74.8 & 73.9 & 22.7 & 22.9 & 22.8 & 1.88 & 1.85 & 1.87 \\
\hline 20 & 73.6 & 74.6 & 74.1 & 23.0 & 23.4 & 23.2 & 1.89 & 1.82 & 1.85 \\
\hline 40 & 73.5 & 74.3 & 73.9 & 23.0 & 24.0 & 23.5 & 1.93 & 1.91 & 1.92 \\
\hline 50 & 73.9 & 72.7 & 73.3 & 21.3 & 23.2 & 22.2 & 1.83 & 1.94 & 1.88 \\
\hline 60 & 73.9 & 74.5 & 74.2 & 22.0 & 23.3 & 22.7 & 1.81 & 1.85 & 1.83 \\
\hline 80 & 74.4 & 74.5 & 74.4 & 23.5 & 22.7 & 23.1 & 1.88 & 1.90 & 1.89 \\
\hline 100 & 73.7 & 73.5 & 73.6 & 23.2 & 23.9 & 23.5 & 1.97 & 1.86 & 1.92 \\
\hline Mean & 73.7 & 74.1 & & 22.7 & 23.3 & & 1.88 & 1.87 & \\
\hline SEM & 0.135 & & & 0.21 & & & 0.019 & & \\
\hline
\end{tabular}

all differences between means and interactions were not significant

TABLE 7

Content of crude ash and calcium in fresh tibia bones, $\%$

\begin{tabular}{|c|c|c|c|c|c|c|}
\hline \multirow{3}{*}{$\begin{array}{l}\% \text { of } 25-\mathrm{OH}-\mathrm{D}_{3} \text { in } \\
\text { whole amount } \\
\text { of added vitamin } \mathrm{D}_{3}\end{array}$} & \multicolumn{3}{|c|}{ Crude ash } & \multicolumn{3}{|c|}{$\mathrm{Ca}$} \\
\hline & \multicolumn{6}{|c|}{$\%$ of grit in whole amount of used calcium carbonate } \\
\hline & 0 & 30 & mean & 0 & 30 & mean \\
\hline 0 & 21.4 & 23.1 & 22.3 & 9.9 & 10.6 & $10.2^{\mathrm{a}}$ \\
\hline 20 & 22.6 & 23.0 & 22.8 & 10.6 & 10.0 & $10.3^{\mathrm{a}}$ \\
\hline 40 & 22.7 & 22.3 & 22.5 & 10.3 & 10.7 & $10.5^{\mathrm{ab}}$ \\
\hline 50 & 21.7 & 24.8 & 23.3 & 9.8 & 12.3 & $11.0^{\mathrm{ab}}$ \\
\hline 60 & 23.3 & 22.8 & 23.1 & 10.3 & 11.3 & $10.8^{\mathrm{ab}}$ \\
\hline 80 & 23.1 & 23.2 & 23.2 & 10.5 & 11.6 & $11.1^{\mathrm{ab}}$ \\
\hline 100 & 22.9 & 23.9 & 23.4 & 10.4 & 12.0 & $11.2^{\mathrm{b}}$ \\
\hline Mean & $22.5^{x}$ & $23.3^{y}$ & & $10.3^{x}$ & $11.2^{\mathrm{y}}$ & \\
\hline SEM & & 0.18 & & & 0.131 & \\
\hline \multicolumn{7}{|l|}{ Effect of: } \\
\hline \multirow{3}{*}{$\begin{array}{l}\text { Ca source } \\
\text { vitamin } \mathrm{D}_{3} \\
\text { interaction } \\
\end{array}$} & \multicolumn{3}{|c|}{ NS } & \multicolumn{3}{|c|}{ * } \\
\hline & \multicolumn{3}{|c|}{$*$} & \multicolumn{3}{|c|}{$* * *$} \\
\hline & \multicolumn{3}{|c|}{ NS } & \multicolumn{3}{|c|}{$* *$} \\
\hline
\end{tabular}

numerical tendency was observed for 3-8\% higher values of relative Ca retention when the 25-OH-D $\mathrm{D}_{3}$ metabolite was supplemented to the diet. Daily retention of phosphorus and relative $\mathrm{P}$ retention (in \% of $\mathrm{P}$ ingested) were the lowest when the diet was supplemented with cholecalciferol (Table 8). Daily P retention 
TABLE 8

Retention and excretion of $\mathrm{Ca}$ and $\mathrm{P}, \mathrm{mg}$ per chicken per day

\begin{tabular}{|c|c|c|c|c|c|c|}
\hline \multirow[b]{2}{*}{ Group } & \multicolumn{3}{|c|}{ Calcium } & \multicolumn{3}{|c|}{ Phosphorus } \\
\hline & $\begin{array}{c}\text { excretion } \\
\text { mg }\end{array}$ & $\begin{array}{c}\text { retention } \\
\text { mg }\end{array}$ & $\begin{array}{c}\text { retention as } \% \\
\text { of intake }\end{array}$ & $\begin{array}{l}\text { excretion } \\
\text { mg }\end{array}$ & $\begin{array}{c}\text { retention } \\
\mathrm{mg}\end{array}$ & $\begin{array}{l}\text { retention as } \\
\% \text { of intake }\end{array}$ \\
\hline I & 255 & $341^{\mathrm{a}}$ & 57.2 & 172 & $222^{a}$ & $56.3^{\mathrm{a}}$ \\
\hline II & 230 & $375^{\mathrm{abc}}$ & 62.0 & 159 & $242^{\mathrm{abc}}$ & $60.3^{\mathrm{bc}}$ \\
\hline III & 244 & $358^{\mathrm{ab}}$ & 59.4 & 170 & $228^{\mathrm{ab}}$ & $57.2^{\mathrm{ab}}$ \\
\hline IV & 260 & $374^{\mathrm{abc}}$ & 58.9 & 163 & $257^{\mathrm{bcd}}$ & $61.0^{\mathrm{bc}}$ \\
\hline V & 263 & $410^{\mathrm{c}}$ & 60.9 & 164 & $281^{\mathrm{d}}$ & $63.1^{\mathrm{c}}$ \\
\hline VI & 262 & $405^{b c}$ & 60.7 & 178 & $263^{\mathrm{cd}}$ & $59.6^{\mathrm{abc}}$ \\
\hline VII & 245 & $393^{\mathrm{bc}}$ & 61.6 & 173 & $250^{\mathrm{abcd}}$ & $59.1^{\mathrm{abc}}$ \\
\hline SEM & 3.98 & 6.49 & 0.526 & 2.12 & 4.91 & 0.559 \\
\hline
\end{tabular}

a,b,c,d - values in columns with different letters differ significantly at $\mathrm{P} \leq 0.05$

significantly increased $(\mathrm{P} \leq 0.05)$ when $70-80 \%$ vitamin $\mathrm{D}_{3}$ was replaced by 25 $\mathrm{OH}-\mathrm{D}_{3}$. The relative $\mathrm{P}$ retention in chickens (as \% of $\mathrm{P}$ intake) increased at vitamin $\mathrm{D}_{3}$ substitution levels of 20,50 and $60 \%$.

\section{DISCUSSION}

The kind of calcium source and range of $25-\mathrm{OH}-\mathrm{D}_{3}$ substitution for cholecalciferol affected chicken performance only in the second period of feeding and for the whole experiment. Incorporation of $30 \%$ of limestone as particulate grit had a positive effect on weight gain, feed intake and the feed conversion ratio. Grit can probably stimulate the digestive tract and nutrient utilization. Compared with diets containing pulverized limestone, a mixture of pulverized and particulate limestone forms increased the percentage ash and calcium contents in the tibia. These findings agree with the results of Zohravi (2002), who used 0.6 to $1.18 \mathrm{~mm}$ and 1.18 to $4.75 \mathrm{~mm}$ particle sized limestone versus less than $0.15 \mathrm{~mm}$. Guinotte et al. (1991) used coarse particles of limestone (greater than $1.18 \mathrm{~mm}$ ) as the sole source of $\mathrm{Ca}$ added to the diet and found a negative effect on performance and bone quality of chickens. These results and the results of the present study suggest that for good performance, chickens require the presence of limestone in powdered form in the diet and that particulate grit should make up only a part of the limestone.

Introduction of the 25-OH-derivative as a partial or complete (50 to 100\%) substitute for cholecalciferol increased body weight gain and improved the feed conversion ratio as compared with chickens fed only vitamin $\mathrm{D}_{3}$. No positive effect was observed at lower levels of substitution. A significant increase of the 
Ca content in the tibia was noted when $25-\mathrm{OH}-\mathrm{D}_{3}$ completely replaced $\mathrm{D}_{3}$ in the diet. This may suggest that synthesis of the active form of cholecalciferol in the liver is not sufficient for chicken performance and bone calcification.

Improvement of body weight in chickens fed $25-\mathrm{OH}-\mathrm{D}_{3}$ as a complete substitute for $\mathrm{D}_{3}$ was reported by Fritts and Waldroup (2003) for diets with added 125-1000 IU D $\mathrm{D}_{3}$ and by Yarger et al. (1995) for diets with $2760 \mathrm{IU} \mathrm{D} \mathrm{D}_{3} \cdot \mathrm{kg}^{-1}$. A greater percentage of bone ash and a lower incidence and severity of tibial dyschondroplasia in chickens fed $25-\mathrm{OH}-\mathrm{D}_{3}$ were reported by Fritts and Waldroup (2003).

The data from the present experiment may suggest that a mixture of pulverized and particulate limestone is a more effective source of calcium than pulverized limestone alone and that addition of the $25-\mathrm{OH}$ vitamin $\mathrm{D}_{3}$ derivative to the diet better covers chickens' requirements for calcium-vitamin $\mathrm{D}_{3}$ metabolism than cholecalciferol. Improved performance was noted when chickens were fed a mixture of particulate and pulverized limestone and when 50 and more percent of the added vitamin $\mathrm{D}_{3}$ was replaced by $25-\mathrm{OH}-\mathrm{D}_{3}$.

The results of the balance trial were consistent with performance and bone ash and $\mathrm{Ca}$ content. Retention of $\mathrm{Ca}$ and $\mathrm{P}$ in chickens increased when cholecalciferol added to the diet was substituted by $25-\mathrm{OH}-\mathrm{D}_{3}$ at a level of $60-100$ and at $70-80 \%$, respectively. Relative $\mathrm{P}$ retention grew significantly at $50-60 \%$ of substitution, but daily $\mathrm{P}$ excretion in excrements was not changed. Substitution of $25-\mathrm{OH}-\mathrm{D}_{3}$ for cholecalciferol did not decrease the emission of $\mathrm{P}$ into the environment. Fritts and Waldroup (2005) reported that phosphorus utilization was not improved as a result of $25-\mathrm{OH}-\mathrm{D}_{3}$ incorporation into a diet with a reduced nonphytate $\mathrm{P}$ content and relatively high vitamin $\mathrm{D}_{3}$ level, supplemented with microbial phytase. This could suggest that the efficacy of $25-\mathrm{OH}-\mathrm{D}_{3}$ is greater at lower levels of dietary vitamin $\mathrm{D}_{3}$ supplementation. At levels typically used by the poultry industry, e.g., 10 to 20 times above NRC (1994) recommendation, the effect of $25-\mathrm{OH}-\mathrm{D}_{3}$ substitution for cholecalciferol on P utilization by chickens is negligible (Fritts and Waldroup, 2005).

\section{CONCLUSIONS}

Replacement of $30 \%$ of pulverized limestone in the diet by particulate grit had a beneficial effect on performance, ash and $\mathrm{Ca}$ content in the tibia. Partial or complete substitution of $25-\mathrm{OH}-\mathrm{D}_{3}$ for the cholecalciferol added to the diet positively affected performance, $\mathrm{Ca}$ content in the tibia, and results of $\mathrm{Ca}$ and $\mathrm{P}$ balance. 


\section{ACKNOWLEDGEMENTS}

The authors gratefully acknowledge the supply of specific vitamin and mineral premixes as gifts from BASF Premixes, Ltd. Kutno (Poland) and Roche Vitamins Ltd, (now DSM), Mszczonów (Poland).

\section{REFERENCES}

AOAC, 1990. Official Methods of Analysis, Association of Official Analytical Chemists. $15^{\text {th }}$ Edition. Arlington, VA

Collins E.D., Norman A.W., 1991. Vitamin D. In: L.J. Machlin (Editor). Handbook of Vitamins. Marcel Dekker, New York, pp. 59-98

Edwards H.M., 1990. Efficacy of several vitamin D compounds in the prevention of tibial dyschondroplasia in broiler chickens. J. Nutr. 120, 1054-1061

European Table of Energy Values for Poultry Feedstuffs, 1989. $3^{\text {rd }}$ Edition. WPSA. Spelderholt Centre for Poultry Research and Information Services, Beekbergen (The Netherlands)

Fritts C.A., Waldroup P.W., 2003. Effect of source and level of vitamin D on live performance and bone development in growing broilers. J. Appl. Poultry Res. 12, 45-52

Fritts C.A., Waldroup P.W., 2005. Comparison of cholecalciferol and 25-hydroxycholecalciferol in broiler diets designed to minimize phosphorus excretion. J. Appl. Poultry Res. 14, 156-166

Guinotte F., Nys Y., Monredon F., 1991. The effects of particle size and origin of calcium carbonate on performance and ossification characteristics in broiler chicks. Poultry Sci. 70, 1908-1920

NRC, 1994. Nutrient Requirements of Poultry. National Research Council. $9^{\text {th }}$ Edition. National Academy Press, Washington, DC

Rennie J.S., Whitehead C.C., 1996. The effectiveness of dietary 25- and 1-hydroxycholecalciferol in preventing tibial dyschondroplasia in broiler chickens. Brit. Poultry Sci. 37, 413-421

Yarger J.G., Saunders C.A., McNaughton J.L., Quarles C.L., Hollis B.W., Gray R.W., 1995. Comparison of dietary 25-hydroxycholecalciferol and cholecalciferol in broiler chickens. Poultry Sci. 74, 1159-1167

Zohravi M., 2002. The effect of source and level of dietary calcium and limestone particle size on performance characteristics and tibia in broiler chicks. Proceedings of $11^{\text {th }}$ European Poultry Conference, Bremen, No. 7867-00203 (CD)

\section{STRESZCZENIE}

\section{Efektywność różnych źródel kredy paszowej i witaminy $\mathrm{D}_{3}$ w żywieniu kurcząt brojlerów}

W 6-tygodniowym doświadczeniu na 560 kurczętach Cobb badano wpływ wprowadzenia do diety żwiru wapiennego oraz 25-hydroksycholekalcyferolu (25-OH-D $)$. Mieszanki paszowe jako źródło wapnia zawierały miałką kredę paszową lub mieszaninę 70\% kredy i 30\% żwiru wapiennego o średnicy cząstek 1.2-4 mm. Witamina $\mathrm{D}_{3}$ (cholekalcyferol) była stopniowo zastępowana przez 25-OH-D : 20, 40, 50, 60, 80 lub 100\%.

Wprowadzenie żwiru wapiennego do mieszanki polepszyło wyniki produkcyjne oraz zwiększyło zawartość popiołu surowego i Ca w kościach piszczelowych. Zastapienie 50 lub 60\% cholekalcyferolu przez 25-OH-D ${ }_{3}$ spowodowało poprawę przyrostu masy ciała i wykorzystania paszy. Całkowite zastapienie witaminy $\mathrm{D}_{3}$ jej pochodną miało dodatni wpływ na zawartość $\mathrm{Ca}$ w kościach piszczelowych, natomiast zastapienie w 50, 60, 80 lub 100\% - na bilans wapnia i fosforu. 